DOI: $10.24193 /$ tras.63E.1

Published First Online: 06/30/2021

\section{DIASPORA START-UP PROGRAMS AND CREATIVE INDUSTRIES: EVIDENCE FROM ROMANIA*}

\author{
Alin CROITORU
}

\author{
Alin CROITORU \\ Lecturer, Center for Social Research, \\ Lucian Blaga University of Sibiu, Sibiu, Romania \\ Tel.: 0040-269-216.062 \\ E-mail: alin.croitoru@ulbsibiu.ro \\ ORCID ID: 0000-0002-6051-7963
}

\begin{abstract}
Romania is one of the main countries of origin for intra-European migration. The national authorities recently implemented the first major program -Diaspora Start-up-to support the business initiatives of Romanian citizens who live abroad and who are interested in opening a business in their home country. This scheme was developed in parallel with a broader program-Romania Start-up Pluswhich was designed to support the entrepreneurial initiatives of individuals residing inside the country. These programs have already supported over 8,600 non-agricultural start-ups created in urban areas. This study conducted a comparative analysis of the two programs based on different criteria and explored their regional dynamics regarding the emergence of start-ups and the prevalence of creative industries companies. The analysis highlighted important regional differences within Romania and revealed that the Diaspora Start-up program registered a statistically significant lower level of businesses registered as part of the creative industries. The results support the formulation of a hypothesis of negative selectivity within the programs designed to support Romanian migrants' entrepreneurship, but further research is needed to test this hypothesis.
\end{abstract}

Keywords: return migration policy, start-up program, Romania, entrepreneurship, return migration.
* Acknowledgements: The author is grateful to Mihai Stelian Rusu for useful comments and constructive suggestions on earlier drafts of the article. This work was supported by a grant of the Romanian Ministry of Education and Research, CNCSUEFISCDI, project number PN-III-P1-1.1-TE-2019-0238, within PNCDI III.

$$
\begin{aligned}
& \text { Transylvanian Review } \\
& \text { of Administrative Sciences, } \\
& \text { No. } 63 \mathrm{E} / 2021, \text { pp. 5-29 }
\end{aligned}
$$




\section{Introduction}

Romania is one of the main countries of origin for intra-European migration (Fries-Tersch et al., 2020; Recchi et al., 2019). To cope with this situation, the political authorities have initiated public debates and started formulating policies focused on managing migration flows and stimulating return migration (Croitoru, 2021; Șerban, 2015; Șerban and Croitoru, 2018). This interest in return policies also exists in other Central and Eastern European countries such as Poland (Karolak, 2020; Lesińska, 2013; Ministry of Economic Development, 2017), Latvia (Kḷave and Šūpule, 2019; Lulle, Zaiga and Bauls, 2019), and Bulgaria (Zareva, 2018). Most of the existing initiatives were developed around the idea that return policies should be selective so that they motivate to return home those individuals who are the most useful in terms of the country of origin's economy and labor market (Boros and Hegedüs, 2016; Wahba, 2015). The literature focused on return migration emphasizes that most of the policies implemented by origin states aim to integrate returnees into the labour market by assisting them to find proper jobs or to start small businesses upon return.

Against this background, returnees have been portrayed as entrepreneurs who have a great potential to contribute to their home country's economy-one of the myths policymakers cherish the most (Sinatti, 2015). Concurrently, officials have started to present small companies in the creative industries as one of the most valuable assets for capitalizing on individuals' human capital and for consolidating economies, as can be seen in European programmatic documents (European Commission, 2011). The overlapping between these two patterns inspired our interest in exploring the propensity of the return migrant entrepreneurs towards these valued niches of entrepreneurship within a unique comparative framework.

Recent Romanian policy initiatives seeking to stimulate the emergence of entrepreneurship through dedicated start-up programs provide an excellent opportunity to reflect on the entrepreneurship of migrants. It also allows us to examine its integration into the regional business ecosystems in Romania. Government officials have designed two parallel programs: Romania Start-up Plus for people who live in Romania and Diaspora Start-up for Romanian citizens who have resided abroad for a minimum of 12 months before joining the program. Both programs began operations in 2018 under the management of the Romanian Ministry of European Funds (MEF). They were created for roughly identical reasons but with one essential difference in eligibility criteria: residence within the country for the first and residence abroad for the second.

The present study seeks to provide a general overview of the Diaspora Start-up program by conducting a series of comparisons with Romania Start-up Plus. The main research objective was to explore the particularities of the former program and to generate an agenda for further research on the topic. To accomplish this objective, we analyze the regional distribution of businesses within the start-up programs and examine their regional profiles by looking at the prevalence of the new companies in the creative industries. 
The remainder of this paper is structured as follows. In the next section, a literature review discusses the main features of Romanian migration patterns and points out the various facets of the relationship between international migration and entrepreneurship. The third section provides an outline of the two start-up programs, discusses their main commonalities, and presents insights into their implementation. The fourth section focuses on methodology, describes the dataset and specifies the operational definition used to identify start-ups belonging to the creative industries. The main findings are presented in the fifth section through a series of comparisons and a map generated specifically for this research. The latter shows the classification of 40 Romanian counties based on their achievements within the Diaspora Start-up program. The last section summarizes the conclusions and discusses them in relation to an agenda for further research on this topic.

\section{Literature review}

Romania is one of the Eastern European countries that went through a double transition period from communism toward democracy and a free market economy (Wolchik and Curry, 2018). This process included major changes in terms of labor opportunities within the country and a gradual growth of the segment of population which searched employment opportunities abroad. During the 1990s, the first phase of the transition encompassed the collapse of the former communist colossal industrial entities (Sucală, 2018) and generated important social problems including, among others, unemployment, deprivation, and violent protests (Croitoru, 2011; Varga, 2014). Rural areas also experienced a brutal de-collectivization process with direct consequences in terms of underdevelopment (Swain, 2013) and the prevalence of subsistence agriculture (Mihalache, 2020; Mihalache and Croitoru, 2011).

Against this background marked by scarce employment opportunities, numerous Romanians used international migration as their last resort (Potot, 2010; Sandu, 2010). These phenomena were affected by important regional dynamics, so emigration flows emerged earlier and developed faster in some regions (Sandu, 2010). However, in 2007, Romania became a member state of the European Union (EU), and the opportunities for international mobility and migration were restructured accordingly. Romanians gained the right to free movement within the borders of the EU and, gradually, the right to work in any other EU country. This contributed to increased migratory flows so that, in 2020 , Romania had over 3.5 million citizens (i.e., over $15 \%$ of the country's population) officially registered as residents in other EU countries (Eurostat, 2021). Simultaneously, the selective nature of migration decreased as international mobility became available to new categories of the population. People emigrated for a broader range of reasons including education and life-style choices, and migrants began to explore new destinations (Sandu, 2017; Sandu, Toth and Tudor, 2018). Finally, return migration became an increasingly accessible option and required less commitment because individuals could re-enter migratory pathways more easily (White, 2014, 
2019). These significant changes along with gradual improvements in the national economy contributed to a smooth shift toward debating and designing policies that stimulate return migration (Croitoru, 2021; Șerban, 2015; Șerban and Croitoru, 2018).

International migration is often presented as an experience that enhances individuals' propensity toward entrepreneurship (Dustmann and Kirchkamp, 2002; McCormick and Wahba, 2001; Sabar and Pagis, 2015), providing them with competitive advantages in setting up new businesses upon return. These benefits are linked to various types of capital (e.g., economic, human, and social). Such advantages fluctuate from one individual to another depending on a series of personal characteristics (e.g., socio-demographic and personality features) and types of migratory experiences (e.g., length of migration, activities performed abroad, and country of destination).

Many scholars have focused on the relationship between migration and returnees' entrepreneurship. The results emphasize that financial savings can be used to capitalize on business initiatives (Black, King and Tiemoko, 2003; Croitoru, 2020) and that the human capital accumulated abroad can endow individuals with skills useful in entrepreneurial projects (Vlase and Croitoru, 2019; Williams, 2007). In addition, transnational social networks can facilitate exchanges of useful information, goods and services (Cosciug, 2017; von Bloh et al., 2020). An exhaustive list of the potential effects of migration cannot be made because this phenomenon is quite heterogenous. Multiple types of migratory experiences can be identified even if the discussion is restricted to economic migrants and to a specific country of origin. The research objective of this article is to find out to what extent the entrepreneurship exhibited by return migrants differs from the entrepreneurial initiatives enacted by individuals living within Romania.

During the communist period, Romania's economy was centralized, planned, and completely controlled by the central government (Sucală, 2018). From 1990 onward, Romanians started to join the capitalist economy through entrepreneurship (Croitoru, 2016; Stoica, 2004, 2012), and recent research has found that entrepreneurship has become a high-status, desirable employment option in Romania. For instance, the Global Entrepreneurship Monitor reports that 75\% of Romanians feel that 'entrepreneurs have high social status' and over $72 \%$ believe that 'entrepreneurship is a good career choice' (Kelley, Singer and Herrington, 2016).

Stimulating entrepreneurship is a general EU objective (European Commission, 2013), but the Romanian authorities have managed to connect these policies to the idea of supporting return migration. This focus is important because, even if proposed policies have been debated previously and added to the agenda of public policies in Romania (Croitoru, 2021), few initiatives have been actually implemented. The Diaspora Start-Up is the main program in terms of size and national coverage, about which further details are provided in the next section.

A broader understanding of business creation and entrepreneurial initiatives also needs to take into account entrepreneurial ecosystems (Schmutzler, Andonova and Perez-Lopez, 2021). Diasporas can become part of these ecosystems through 
multiple mechanisms that include the financial savings and remittances of migrants (Schmutzler, Andonova and Perez-Lopez, 2021), knowledge transfer, spillover effects (Liu et al., 2010), and transnational social fields (von Bloh et al., 2020). Entrepreneurial ecosystems thus shape the general dynamics of business creation and the prevalence of specific economic activities. Within the paper, attention is paid to the relationships between the regional entrepreneurial ecosystems and the regional dynamics of the start-up programs. One can expect that the program implemented for residents within the country to better reflect regional ecosystems, while the dynamic of the Diaspora start-up to be driven by other forces as well.

The overall development of the creative industries and creation of businesses engaging in these kinds of activities are considered essential components of the EU's policy agenda (Cooke and De Propris, 2011). As such, they have received significant attention in the programmatic documents of the European Commission (2011). Multiple definitions have been developed of the creative industries, but the present research used Higgs, Cunningham and Bakhshi's (2008) conceptualization. The cited authors label businesses as creative when they 'have their origin in individual creativity, skill and talent and (...) have a potential for wealth and job creation through the generation and exploitation of intellectual property'.

Creativity can be applied in all business activities. As the field of research developed, multiple studies focusing on entrepreneurship have emphasized the importance of human creativity (e.g., Schumpeter, 2008). However, the current analyses and policies link the creative industries to particular business activities (e.g., advertising, arts and culture, media, design, and information technology [IT]). The operational definition of creative industries employed in this paper is provided in the methodology section along with the list of economic activities included within this term.

A series of studies have revealed that the creative industries' development in Romania has been significantly affected by regional dynamics, so these businesses appear more frequently in some parts of the country (i.e., specific counties and cities) and more rarely in others (Cojanu, Pîslaru and Botezatu, 2016; Croitoru et al., 2016; Voicu and Dragomir, 2016). Thus, both start-up programs under study are expected to reflect, at least partially, regional entrepreneurial ecosystems. The present study also seeks to examine more closely whether the emergence of creative businesses of migrants is somehow different compared to entrepreneurs already residing within the country.

\section{Outline of Romania Start-up Plus and Diaspora Start-up programs}

The two programs in question were concomitantly implemented by the MEF to increase employment opportunities through entrepreneurship within the less developed regions of Romania (all regions were eligible, excepting Bucharest-Ilfov which was evaluated as a highly-developed region). The general idea was to support individuals who intend to create a business via a complex mechanism that includes 
training in business administration, legal counselling, and financial subsidies. These programs have a quite similar design and target people interested in starting a business in the urban areas of Romania and only non-agricultural economic activities are eligible.

More specifically, the Diaspora Start-up program includes particular eligibility criteria addressed to the Romanian citizens living abroad who are interested in starting a business in Romania. This program has been the main strategy implemented to stimulate return migration and capitalize on the human capital of return migrants. Diaspora Start-up requires eligible Romanian migrants to provide specific documents confirming their residence abroad for at least 12 months before their enrollment in the start-up program, as well as proof of their entrepreneurial competencies (see Table 1).

These start-up programs were implemented in two distinct phases, and both programs have a regional component. During the first phase, a series of middle-level agencies were selected through a competition to manage smaller scale grant schemes (i.e., projects). The projects were designed and financed to provide training for a larger group of potential beneficiaries, select the best business plans for start-ups based on a series of criteria approved by the MEF, and monitor and supervise the start-ups. The programs allowed a middle-level agency to manage projects within both Start-up schemes (Romania Start-up Plus and Diaspora Start-up) and some of these agencies succeeded to implement parallel programs with similar designs but specific targeting groups based on the residency of the beneficiaries (in Romania or abroad).

In the case of Diaspora Start-up, some projects were oriented toward attracting migrant entrepreneurs from specific countries of destination (e.g., Italy, Spain, Hungary, and Greece). Other projects accepted Romanian citizens living abroad into the program regardless of their country of residence. The 35 projects implemented within Diaspora Start-up are managed by private companies (16 projects) and non-governmental organizations (12 projects), public universities (2 projects), and other organizations ( 5 projects). During the second phase, these agencies had to provide subsidies to 1,065 start-ups. The number of businesses supported varies from 22 to 76 start-ups per project, but the average is 36 start-ups per project. Given the numerous commonalities between these programs, the present study developed an analytical framework to examine their relationships with regional entrepreneurial ecosystems and identify the specificities of the Diaspora Start-up program.

\section{Methodology}

This research employs a quantitative methodology to analyze official statistics derived from the implementation of the two programs: Romania Start-up Plus and Diaspora Start-up. Two interconnected objectives guided the analyses. The first step was to explore the regional dynamics of the programs and their relationships with regional entrepreneurial ecosystems regarding the emergence of new businesses. In the second step, the prevalence of the start-ups in the creative industries was used to 


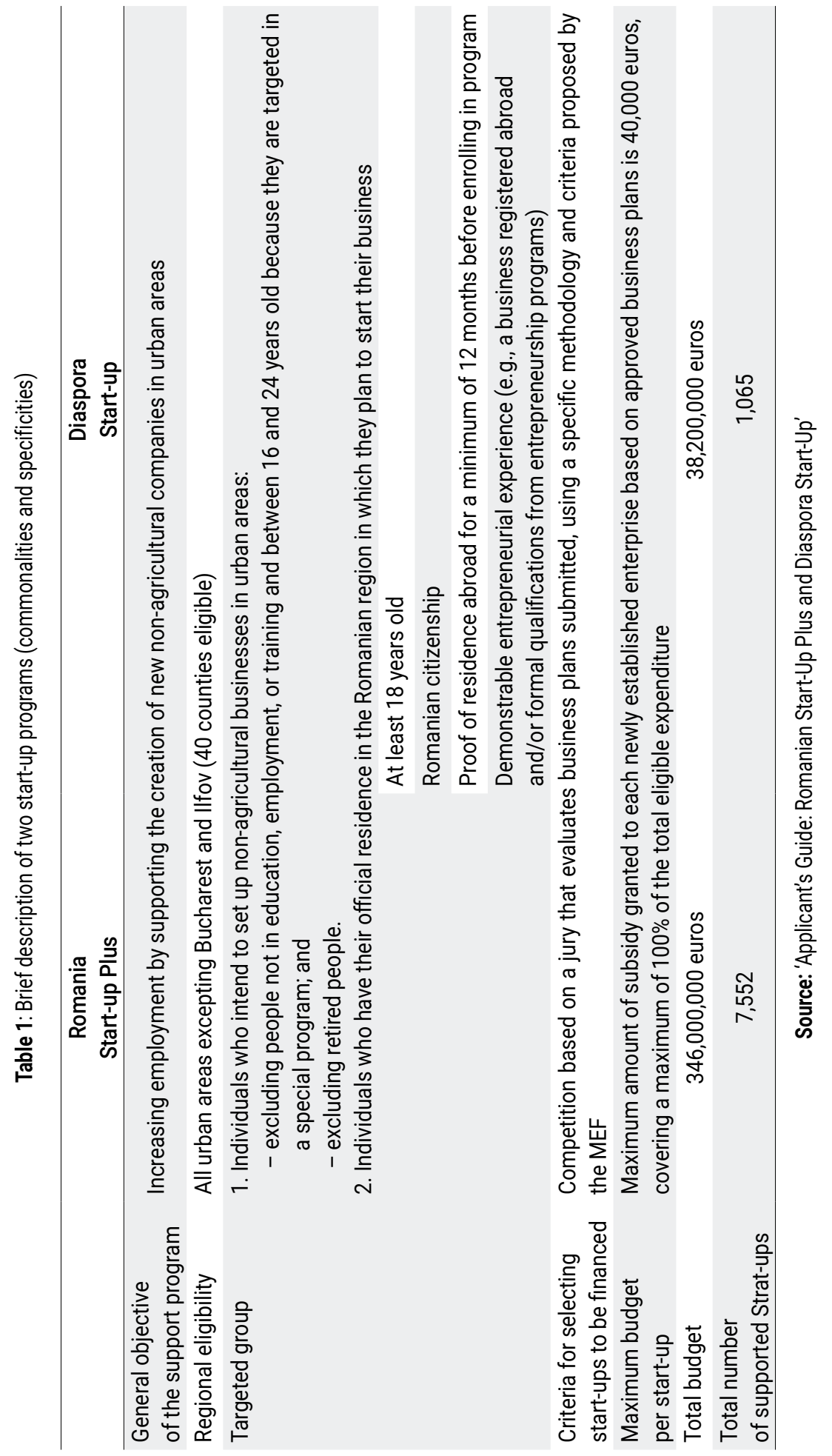


compare the two programs and examine their relationships with the regional dynamics of the creative industries within Romania.

The data on the two programs were requested by submitting an official letter to the MEF in 2020. The dataset provided by the MEF included the total population of start-ups financed in each program. The following synthetic data were provided: the name of the company, the county in which the company is registered (i.e., out of the 40 counties eligible), and the economic activity code registered according to the Classification of National Economic Activities in Romania (CAEN).

The operational definition of creative industries used in this study was taken from Volintiru and Miron's (2014) analysis of the creative industries in Romania, including the specific CAEN codes (see Table 2). Binary variables were constructed so that the businesses that registered under the CAEN codes listed as belonging to the creative industries were categorized as a part of these industries. All the other new companies were included in a contrasting general category (see the explanation in the last column of Table 2).

Table 2: Creative industries within CAEN

\begin{tabular}{|c|c|c|}
\hline Economic activities & CAEN codes & Description \\
\hline 1. Architecture & 7111 & \multirow{9}{*}{$\begin{array}{l}\text { Companies with any of these CAEN } \\
\text { codes were put into the creative in- } \\
\text { dustries category, and businesses } \\
\text { with any other codes were placed } \\
\text { in a contrasting category (i.e., other } \\
\text { industries). }\end{array}$} \\
\hline 2. Arts and culture & $9001,9002,9003$ & \\
\hline 3. Crafts & $\begin{array}{l}\text { 1391, 1393, 1420, 1431, } 1439, \\
1511,1512,1520\end{array}$ & \\
\hline 4. Design & 7410 & \\
\hline 5. Media & $\begin{array}{l}1820,5911,5912,5914,5914, \\
5819,5920,6010,6020,7420\end{array}$ & \\
\hline 6. Advertising & $7311,7312,7320$ & \\
\hline 7. Software, Web, and IT & $\begin{array}{l}5821,5829,6201,6209,6311 \\
6312,6391,6399\end{array}$ & \\
\hline 8. Sports and entertainment & $9311,9312,9313,9319,9321,9329$ & \\
\hline $\begin{array}{l}\text { 9. Printing, editing, translating, } \\
\text { and interpreting }\end{array}$ & $\begin{array}{l}1811,1812,1813,1814,5811, \\
5812,5813,5814,5819,7430\end{array}$ & \\
\hline
\end{tabular}

Source: Volintiru and Miron (2014, p. 291)

To describe regional entrepreneurial ecosystems and facilitate comparisons, standardization was achieved by including data on the size of the population. The data provided by the MEF were linked to other public population statistics and information about the total number of new companies (Table 3). In addition, data on the creative industries at a regional level were drawn from the Index of Creative Industries (ICI) calculated for urban areas from all the 40 counties introduced in our analyses (Voicu and Dragomir, 2016). This index is relevant for the entrepreneurial ecosystem at the regional level and it is a standardized measurement based on indicators regarding the profitability, revenue size, and number of employees of local entities classified 
as part of the creative industries. For the most recent available year (2015), the index varies from -1.60 to +3.22 and higher values of the ICI indicate higher development of the creative sectors within the urban areas of the county. Analyzing local datasets from 2010 to 2015, Voicu and Dragomir (2016, p. 51) emphasize that ICI is a reliable measurement for the potential of the creative economy within the local economy and can be used in comparative regional analyses.

The article uses a series of indicators built on data which are publicly available and this methodological strategy has certain advantages and implicit limits. On the one hand, it creates excellent premises for the replicability of the study along with the possibility to extend the results by adding new series of data regarding the entrepreneurial ecosystems or linked to the development of the two Start-up programs. At the same time, it provides a useful methodological framework for analyzing future governmental programs designed on a similar logic. On the other hand, there are certain limits derived from the aggregation of the data by different institutions and the formats in which the data are publicly available. For instance, the two Start-up programs have the data aggregated at county level-urban areas, but indicators for the new registered companies were available at county level without differentiating between urban and rural areas. Based on the argument that the entrepreneurial ecosystems exceed the formal borders of a single locality (Schmutzler, Andonova and Perez-Lopez, 2021) and multiple factors shape the emergence of the new companies, we decided to explore the two Start-up programs in relation to indicators which are relevant for the broader regional entrepreneurial ecosystem (county level). These contextual factors allow us to better understand the regional dynamics of the two programs and to recognize commonalities or differences whenever the case. To sum up the multiple data used within the article, we provide in Table 3 a series of details about all the indicators introduced into the analysis.

\section{Results}

The main results reported in this paper are organized in thematic subsections as follows. First, an analysis was conducted for identifying the regional dynamic of each program. To examine the relationships of the programs with regional entrepreneurial ecosystems, these programs were correlated with the rate of new business creation at the level of the county. Second, the analysis focused on the specificity of the businesses and compared the prevalence of start-ups in the creative industries within the two programs at the national and county levels. The programs' integration into entrepreneurial ecosystems was then correlated with the Index of Creative Industries.

\subsection{Romania Start-up Plus and Diaspora Start-up's regional dynamics}

Firstly, the prevalence of the start-ups is examined at county level in terms of its correlation with the overall creation of new companies in Romania during 2018. Secondly, an overview of the two programs' regional dynamics at the county level is provided and discussed. 


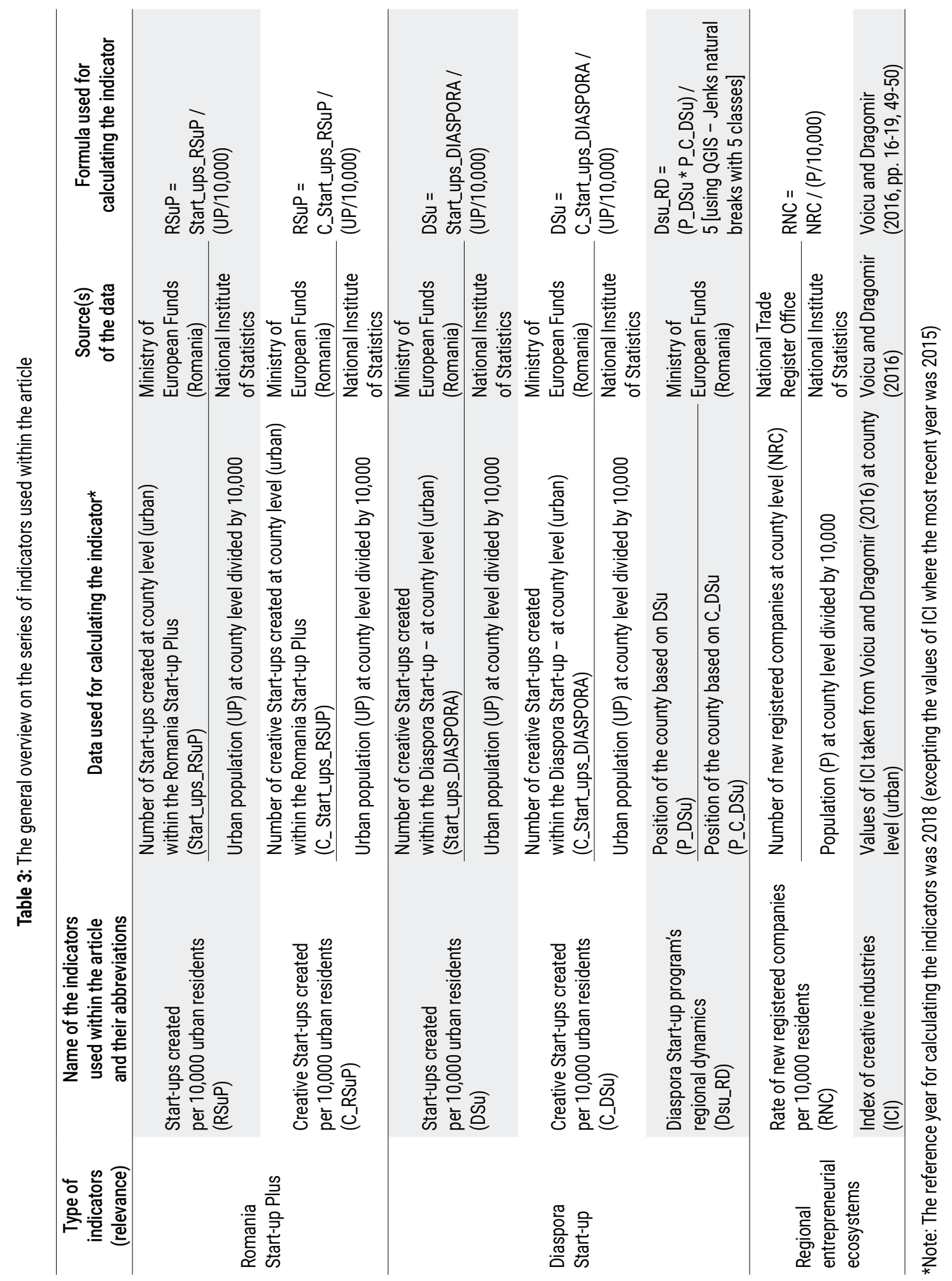


A correlation matrix was constructed to find out whether these two Romanian government programs reflect the regional dynamics of entrepreneurship creation in Romania (Table 4). At the county level, the results reveal no statistically significant correlations between the rate of newly registered companies in 2018 and the rate of start-ups financed through the two programs. However, a statistically significant, moderate relationship was found between the counties' rates within the two start-up programs (Pearson's correlation coefficient $r=0.39 ; p<0.05$ ). Since this correlation is positive, those counties in which the rate of companies enrolled in Romania Start-up Plus was higher also registered substantially higher rates in the Diaspora Start-up.

Table 4: Correlations between the rate of the new registered companies and the rate of Start-Ups registered within the two programs (county level)

\begin{tabular}{|c|c|c|c|c|}
\hline & & 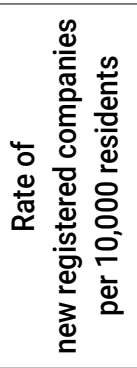 & 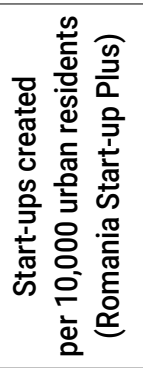 & 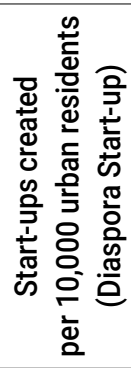 \\
\hline \multirow{3}{*}{$\begin{array}{l}\text { Rate of } \\
\text { new registered companies } \\
\text { per } 10,000 \text { residents }\end{array}$} & $r$ & 1 & -.156 & .027 \\
\hline & $p$ & & .337 & .867 \\
\hline & $\mathrm{N}$ (counties) & 40 & 40 & 40 \\
\hline \multirow{3}{*}{$\begin{array}{l}\text { Start-ups created } \\
\text { per } 10,000 \text { urban residents } \\
\text { (Romania Start-up Plus) }\end{array}$} & $r$ & -.156 & 1 & $.391^{\star}$ \\
\hline & $p$ & .337 & & .013 \\
\hline & $\mathrm{N}$ (counties) & 40 & 40 & 40 \\
\hline \multirow{3}{*}{$\begin{array}{l}\text { Start-ups created } \\
\text { per } 10,000 \text { urban residents } \\
\text { (Diaspora Start-up) }\end{array}$} & $r$ & .027 & $.391^{*}$ & 1 \\
\hline & $p$ & .867 & .013 & \\
\hline & $\mathrm{N}$ (counties) & 40 & 40 & 40 \\
\hline
\end{tabular}

*. Correlation is significant at the 0.05 level (2-tailed).

This regional dynamic is further documented in Figure 1. This indicates a negative relationship between the rate of new registered companies in 2018 at the county level and the rate of businesses created within Romania Start-up Plus. In many counties, this program was not driven by the entrepreneurial ecosystem's needs but instead by other factors.

The intersection of the types of data showed in Figure 1 reveals diverse regional contexts. Counties with the highest rate of new created companies (i.e., Cluj and Timiș) in 2018 registered only average values regarding the rate of newly created companies within the Romania Start-up Plus program. Most counties within this program were characterized by moderate values regarding the rate of newly created businesses (i.e., Alba, Dâmbovița, Gorj, Dolj, Tulcea, and Vâlcea). However, some 


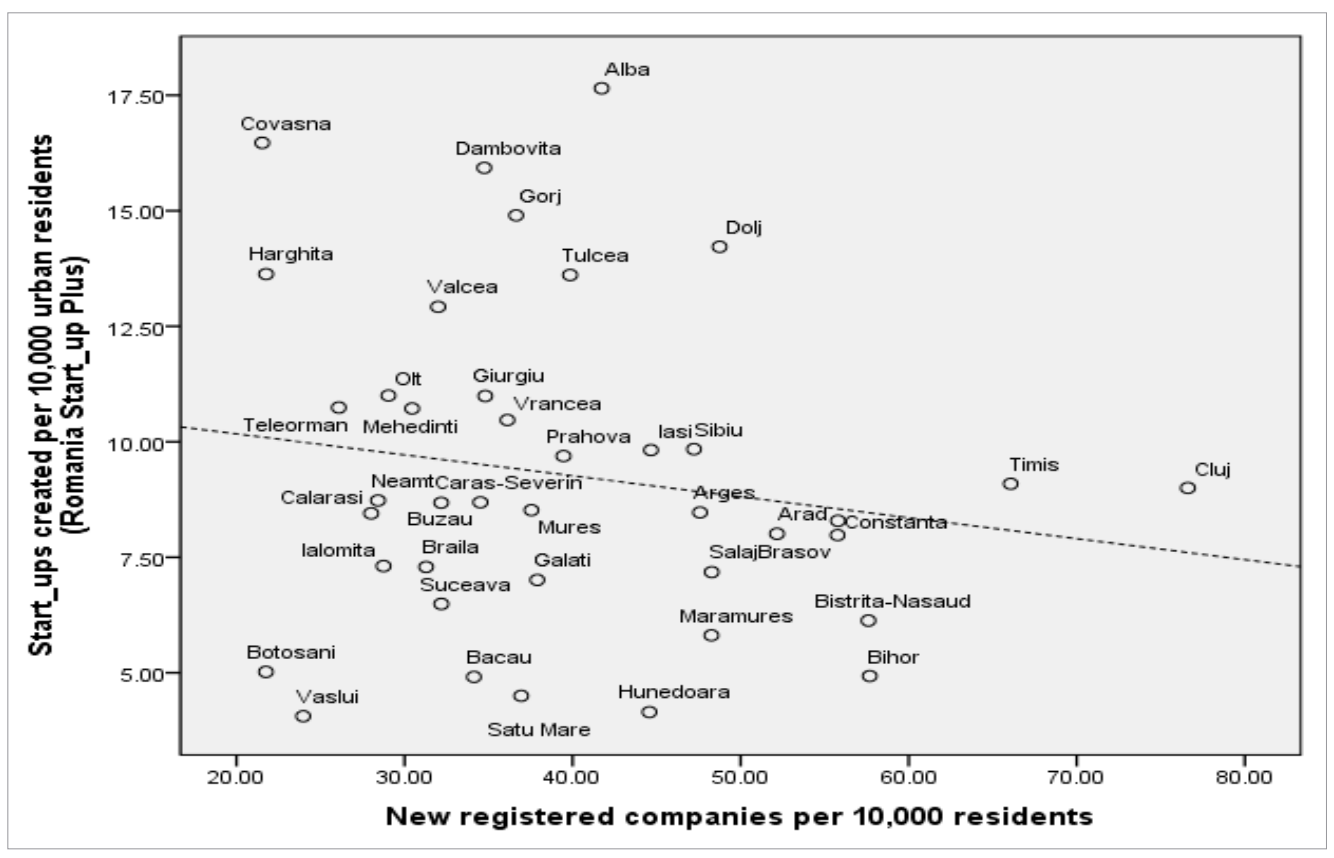

Figure 1: Rate of newly created companies and rate of start-ups created within Romania Start-up Plus (at county level)

Source: Author's own calculation

counties succeeded in achieving extremely high rates within Romania Start-up Plus even if they had previously reported lower rates of new companies (i.e., mainly Covasna and Harghita). Finally, Figure 1 above confirms a strong correlation between the two indicators in Botoșani and Vaslui, both of which registered extremely low values. In short, this graph reveals that low levels are correlated for the two indicators with a few exceptions-and some clusters of successful counties appear within the Romania Start-up Plus program: Covasna and Harghita are geographically neighboring counties; Gorj, Dolj, and Vâlcea are also adjacent; but the other counties are relatively isolated from each other.

Figure 2 adds new findings based on a comparison of the rate of newly registered companies in 2018 at the county level with the rate achieved by the Diaspora Start-up program. Some similarities can be detected with the results presented previously. Diaspora Start-up appears to have no relationship with regional dynamics regarding the emergence of new companies in 2018. The counties with the highest rates of new businesses (i.e., Cluj and Timiș) had moderate-to-low values within this program. However, some of Romania Start-up Plus best performers also achieved remarkable results in Diaspora Start-up (i.e., Covasna, Alba, Harghita, and Gorj).

In contrast, a series of new counties had moderate values within Romania Start-up Plus, but they were more successful within the Diaspora Start-up program (i.e., Mureș, 


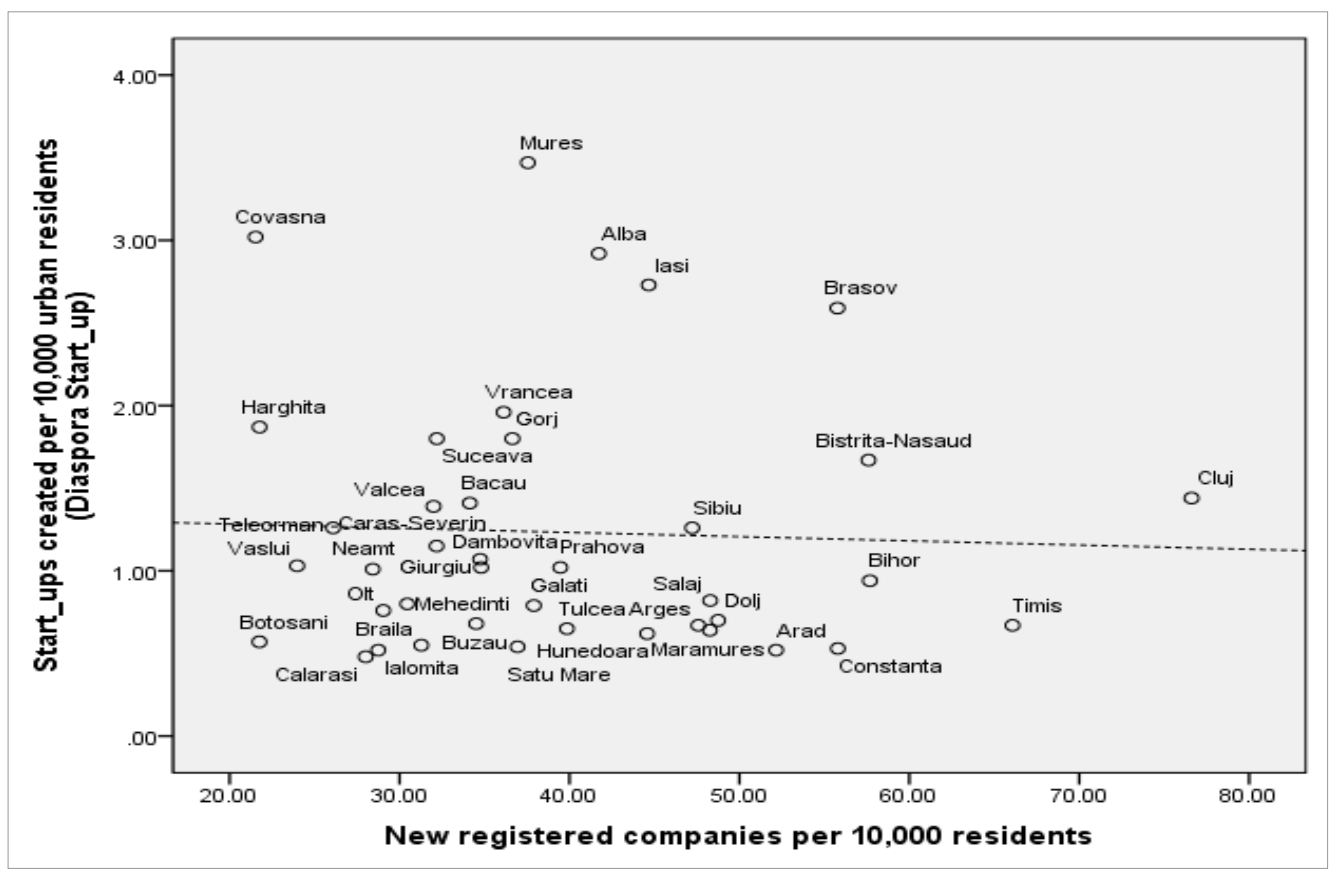

Figure 2: Rate of new companies and rate of start-ups created within the Diaspora Start-up (county level)

Source: Author's own calculation

Iași, Brașov, Vrancea, and Suceava). In term of regional concentrations, a cluster of four counties is located in the central part of Romania (i.e., Mureș, Covasna, Braşov, and Harghita, which are neighboring counties), while the others are isolated performers. However, the reader should interpret these results within the limits of the methodology presented above. Certainly, further research can benefit from adding new indicators about the entrepreneurial ecosystems or by moving the entire analysis at local level (if and when the data will become available at this level).

Certain factors connect the two start-up programs, which have shaped their development. Further research needs to be conducted to confirm if participants in Romania Start-up Plus helped their social connections living abroad (i.e., relatives and friends) to participate in the Diaspora Start-up. Another possibility is that the agencies (i.e., private companies and public institutions) that implemented the start-up programs generated clustering effects in the two programs for certain counties.

\subsection{Creative industries: comparison of two start-up programs}

This study also sought to analyze the emergence of companies in the creative industries associated with the two programs at a national and regional level. The comparison was conducted based on the conceptualization of these industries provided in the methodology section. The data processed for this purpose included the entire population of start-ups financed through the two programs, and a new indicator rel- 
evant for the entrepreneurial ecosystem which was also incorporated as part of the methodology (i.e., the Index of Creative Industries).

Table 5 provides the results of the analyses conducted at national level. A distinction was made between start-ups registered as part of the creative industries and those that belong to other industries. Notably, the share of companies in the creative industries is higher for Romania Start-up Plus (27.3\%) than for Diaspora Start-up $(20.1 \%)$.

Table 5. Start-ups registered as creative industries by program (at national level)

\begin{tabular}{lcccccc}
\hline & \multicolumn{2}{c}{ Creative industries } & \multicolumn{2}{c}{ Other industries } & \multicolumn{2}{c}{ Total } \\
\cline { 2 - 7 } & Number & $\%$ & Number & $\%$ & Number & $\%$ \\
\hline Romania Start- up Plus & 2,058 & $27.3 \%$ & 5,494 & $72.7 \%$ & 7,552 & $100 \%$ \\
Diaspora Start- up & 214 & $20.1 \%$ & 851 & $79.9 \%$ & 1,065 & $100 \%$ \\
Total & 2,272 & $26.4 \%$ & 6,345 & $73.6 \%$ & 8,617 & $100 \%$ \\
\hline
\end{tabular}

Source: Author's own calculation

Pearson's Chi-squared test revealed a statistically significant association $(p<0.001)$ between the type of program and the prevalence of start-ups in the creative industries. The lower propensity toward the creative industries within the Diaspora Start-up program shows that returning migrants have a distinct entrepreneurial profile. This finding challenges the prevalent notion that their businesses are more innovative as compared to other entrepreneurs already residing in their home country.

The analyses performed on this dataset also revealed that the two programs have specific profiles in terms of economic activities of the start-ups. To identify differences between the two programs, the typology developed by Volintiru and Miron (2014) was applied. However, within the last category, the subcategories of translating and interpreting were separated from printing and editing because migration experiences can contribute to individuals' skills and expertise in these areas (see Table 6). The results illustrate which niches of the creative industries included most of the start-ups from the two programs.

In addition, the analyses assessed the statistical significance of the association between the type of program and the new businesses in particular economic activities. The findings reveal that, first, most creative start-ups are concentrated in three domains: sports and entertainment (6.8\%), media (6.5\%), and software, Web, and IT (5.5\%). The higher share of creative businesses included in the software, Web, and IT category was also confirmed by Volintiru and Miron's (2014) study of creative industries in Bucharest. However, comparisons should be carried out with all due caution because the cited authors analyzed that entire population of businesses in Bucharest and not just start-ups financed through government programs.

Second, four domains of activity in which most start-ups engage have a statistically significant association with the type of program: arts and culture, media, sports and 
Table 6: Structure of creative industries by program (at national level) percentages from the total number of start-ups created within each program

\begin{tabular}{lcccc}
\hline & $\begin{array}{c}\text { Romania } \\
\text { Start-up Plus }\end{array}$ & $\begin{array}{c}\text { Diaspora } \\
\text { Start-up }\end{array}$ & Total & $p$ \\
\hline Architecture & $0.8 \%$ & $1 \%$ & $0.8 \%$ & 0.392 \\
Arts and culture & $1.6 \%$ & $0.7 \%$ & $1.5 \%$ & 0.018 \\
Crafts & $0.3 \%$ & $0.1 \%$ & $0.2 \%$ & 0.317 \\
Design & $1.1 \%$ & $0.8 \%$ & $1 \%$ & 0.494 \\
Media & $6.9 \%$ & $3.1 \%$ & $6.5 \%$ & 0.000 \\
Advertising & $2.1 \%$ & $2.1 \%$ & $2.1 \%$ & 0.977 \\
Software, Web, and IT & $5.5 \%$ & $5.9 \%$ & $5.5 \%$ & 0.519 \\
Sports and entertainment & $7 \%$ & $5.4 \%$ & $6.8 \%$ & 0.053 \\
Printing and editing & $2.7 \%$ & $1.7 \%$ & $2.6 \%$ & 0.044 \\
Translating and interpreting & $0.2 \%$ & $0.5 \%$ & $0.3 \%$ & 0.171 \\
\hline
\end{tabular}

Source: Author's calculations for two programs based on the typology developed by Volintiru and Miron (2014)

entertainment, and printing, editing, translating, and interpreting. All these domains attracted a higher share of the Romania Start-up Plus businesses versus lower rates in the Diaspora Start-up program. In contrast, Diaspora Start-up recorded higher percentages compared to Romania Start-up Plus in two areas-architecture and software, Web, and IT-but these links were rather weak and not statistically significant. Last, a meaningful distinction can be made within the category of printing, editing, translating, and interpreting when the two programs are compared. The share of start-ups in translating and interpreting is higher in Diaspora Start-up, although this association is also not statistically significant.

Correlation analysis at county level was also conducted to gain insights into the connections between the regional dynamics of the creative start-ups emerged within the two programs and regional entrepreneurial ecosystems measured through the Index of Creative Industries. Table 7 shows that no statistically significant correlations were found between the rate of companies created in the creative industries within the Romania Start-up Plus program and the Index of Creative Industries. However, a moderately strong positive correlation exists between the rate of businesses in the creative industries supported by the Diaspora Start-up program and the Index of Creative Industries (Pearson's correlation coefficient $r=0.36$; $p<0.05$ ). Finally, the two regional dynamics of the programs are positively correlated to a moderate degree (Pearson's correlation coefficient $\mathrm{r}=0.39 ; p<0.05$ ).

Similar to the previous subsection focused on the relationships between regional entrepreneurial ecosystems and the two start-up programs' regional dynamics, the analyses included graphic comparison at the county level. Several particularities were revealed by a comparison of counties' values on the Index of Creative Industries with their rates of start-ups created in the creative industries through the Romania Start-up Plus program (see Figure 3). 
Table 7: Correlations between the Index of creative industries and Creative Start-ups created within the two programs

\begin{tabular}{llcccc}
\hline & & $\begin{array}{c}\text { Index of } \\
\text { creative } \\
\text { industries }\end{array}$ & $\begin{array}{c}\text { Creative Start-ups created } \\
\text { per 10,000 urban residents } \\
\text { (Romania Start-up Plus) }\end{array}$ & $\begin{array}{c}\text { Creative Start-ups created } \\
\text { per 10,000 urban residents } \\
\text { (Diaspora Start-up) }\end{array}$ \\
\hline & $\mathrm{r}$ & 1 & .166 & $.356^{*}$ \\
Index of creative industries & $p$ & & .306 & .024 \\
& $\mathrm{~N}$ & 40 & 40 & 40 \\
\hline Creative Start-ups created & $\mathrm{r}$ & .166 & 1 & $.391^{*}$ \\
per 10,000 urban residents & $p$ & .306 & & .013 \\
(Romania Start-up Plus) & $\mathrm{N}$ & 40 & 40 & 40 \\
\hline Creative Start-ups created & $\mathrm{r}$ & $.356^{*}$ & $.391^{*}$ & 1 \\
per 10,000 urban residents & $p$ & .024 & .013 & 40 \\
(Diaspora Start-up) & $\mathrm{N}$ & 40 & 40 & \\
\hline
\end{tabular}

*. Correlation is significant at the 0.05 level (2-tailed).

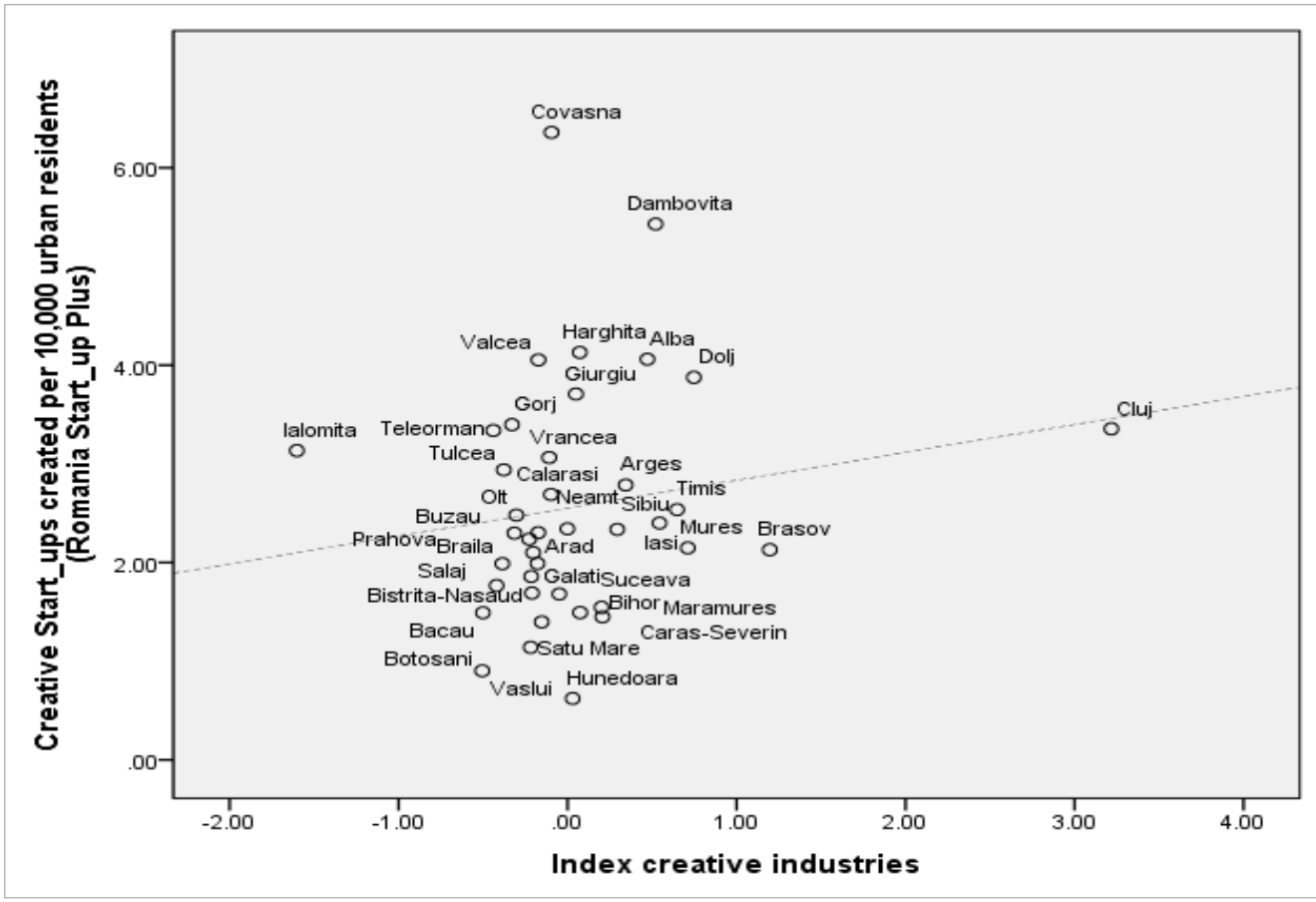

Figure 3: Index of creative industries and rate of start-ups in creative industries within Romania Start-up Plus (at county level)

Source: Author's own calculation

Cluj is by far the most fertile context for the creative industries (Voicu and Dragomir, 2016), but this county has only moderate results in the Romania Start-up 
Plus program regarding the rate of start-ups registered in the creative industries. While two counties have obtained remarkably high rates in terms of creative startups within this program (i.e., Covasna and Dambovița), others with quite similar values on the Index of creative industries have had quite low rates of new creative start-ups (e.g., Hunedoara). These results strengthen the previously mentioned argument that the regional dynamic of the Romania Start-up Plus have been only weakly connected to regional entrepreneurial ecosystems and the program has been influenced more strongly by other factors. However, the results also reveal a low instrumental value in terms of correcting socioeconomic disparities since only a few counties with extremely low values on the Index of Creative Industries have recorded moderate-to-high levels of creative start-ups in the Romania Start-up Plus program (e.g., Ialomița).

An analysis of Diaspora Start-up's regional dynamics, in turn, indicated a moderately strong positive relationship between the rate of creative businesses started and the Index of Creative Industries. Figure 4 presents part of the results for illustrating the performance of the 40 counties in terms of creating start-ups within this program, again pointing out a large cluster in the central part of Romania but with a different hierarchy (i.e., Harghita, Mureș, Covasna, Alba, Brașov, Sibiu and Bistrița-Năsăud, which are neighboring counties). Most of these central counties recorded relatively

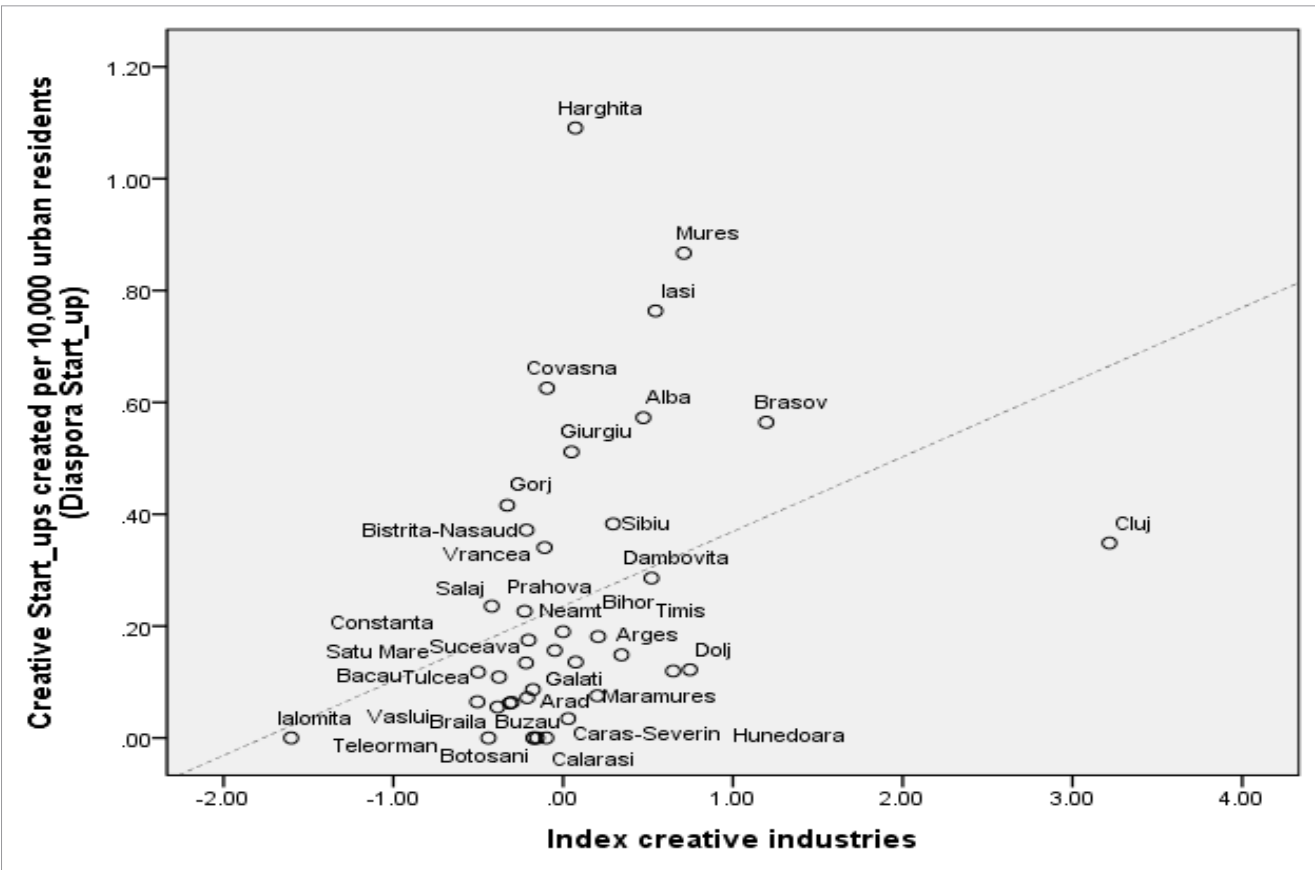

Figure 4: Index of creative industries and rate of start-ups in creative industries through Diaspora Start-up (at county level)

Source: Author's own calculation 
moderate-to-high values regarding the Index of Creative Industries. A few other counties are rather isolated stronger performers in terms of the rate of creative industries start-ups created through the Diaspora Start-up program, namely, Iași, Giurgiu, Gorj.

Further, the analysis will be focused on the regional performance within the diaspora Start-up. We advance a map which reflects the intersecting county hierarchies based on the two indicators mentioned previously: the rate of Diaspora Start-up businesses per 10,000 urban residents and the rate of Diaspora Start-up companies registered as creative industries per 10,000 urban residents (Figure 5). Given the data's specificity, natural breaks were used to cluster the 40 counties into five classes even if the divisions produced unequal categories.

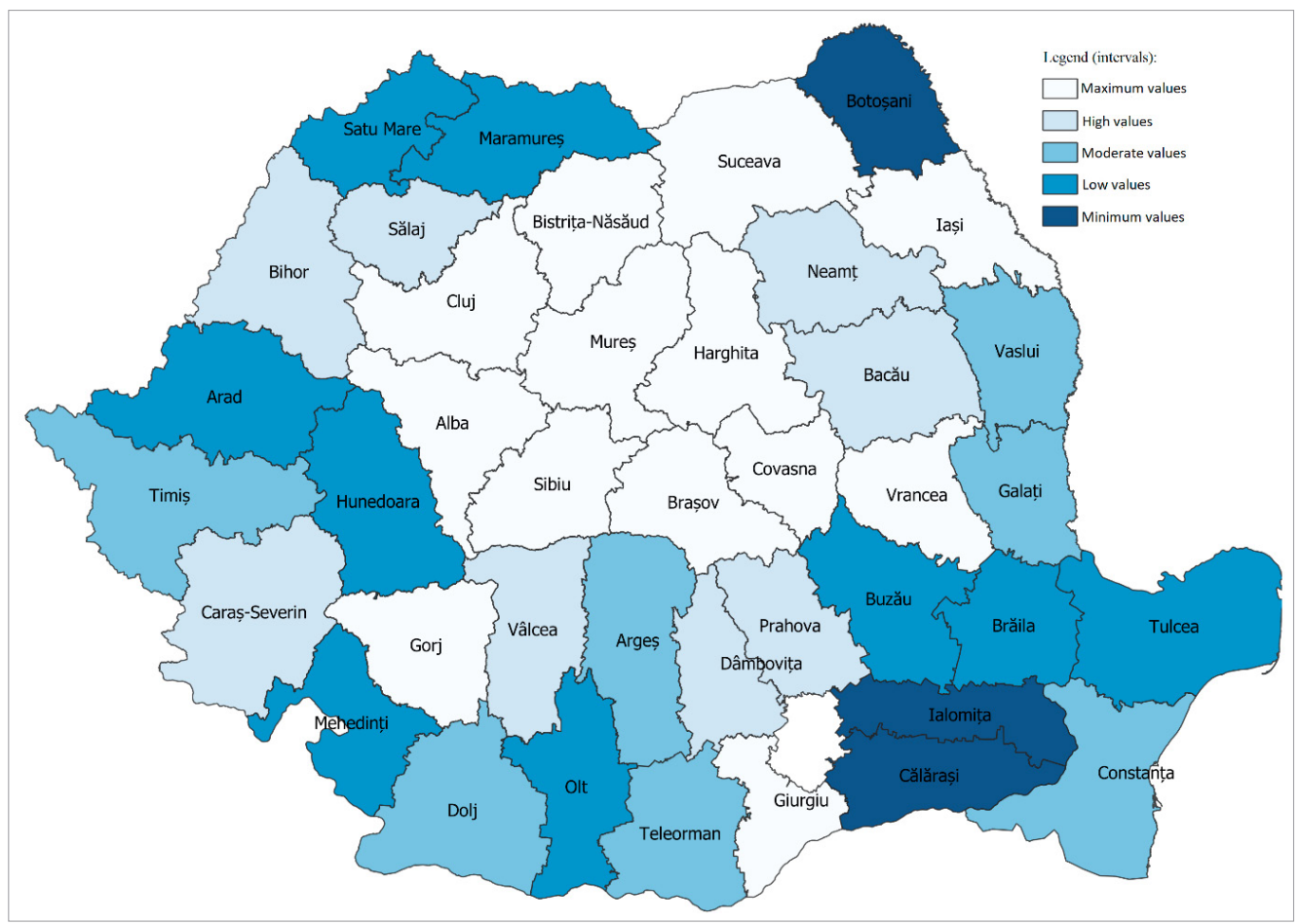

Figure 5: Diaspora Start-up program's regional dynamics (intersecting hierarchies)

Source: Author's own calculation, using QGIS software, with Jenks natural breaks-five classes

The counties included in the category with maximum values were expected to be the main beneficiaries of start-ups supported by the Diaspora Start-up program. Higher rates for both indicators produced the maximum values. For instance, Mureș has the highest rate regarding Diaspora Start-up companies and the second highest score in terms of creative industries. Intersecting these criteria, we can find that most of these counties are located within the central part of Romania (i.e., Harghita, 
Covasna, Alba, Brașov, Bistrița-Năsăud, Cluj, and Sibiu). The data, however, indicated the central counties are also somewhat similar to three Moldavian counties (i.e., Iași, Suceava, and Vrancea), as well as to two others in the south (i.e., Gorj and Giurgiu). At the other end of the hierarchy appear two southern counties (i.e., Ialomița and Călărași) and the northern county from Moldova (i.e., Botoșani). These counties registered low achievements within the Diaspora Start-up program.

As mentioned previously, a possible explanation for these differences is that they may be in part linked to the entrepreneurial ecosystem in terms of creative businesses. The results also suggest an important line of inquiry regarding the concentration of the benefits of migrants' entrepreneurship in specific areas of Romania because of government programs. However, an analysis of the relationships between the regional dynamics of the rate of Diaspora Start-ups per 10,000 urban residents and the share of new businesses in the creative industries within the same program revealed an extremely low Pearson's correlation coefficient ( $\mathrm{r}=0.295 ; p<0.10)$. Reinforcement through slight effects can be observed in regions where Diaspora Start-up has been more successful (i.e., a higher rate of start-ups created per 10,000 people) given that the share of start-ups in the creative industries is noticeably higher in these counties.

\section{Conclusions and discussion}

The results provide a new perspective on the implementation of the Diaspora Start-up in Romania. A series of comparisons were made between this program focused on supporting migrants' entrepreneurship in their country of origin and a similar broader program dedicated to people already residing in Romania (i.e., Romania Start-up Plus). The analyses selected key features of Romanian migration and the interest of the Government in promoting return migration. Concurrently, the emergence of new businesses was understood to be dependent on regional entrepreneurial ecosystems. In this context, the prevalence of businesses in the creative industries constituted fertile ground in terms of identifying the particularities of the programs and their integration into regional entrepreneurial ecosystems.

The data analyses highlighted several differences between the two programs under study. First, their regional dynamics are positively correlated to a moderate degree, but neither program has a statistically significant correlation with the overall regional dynamics of firm emergence in Romania. Evidently, the rate of new firms created within these programs has evolved independently, and neither reinforces the existing differences or counterbalances them in a statistically significant way.

The Diaspora Start-up can be evaluated as a successful program because it attracted over 1,000 Romanian migrants to create businesses in Romania. However, we can also learn important lessons from its implementation. We observed that the Diaspora Start-up has a significantly lower share of businesses within the creative industries (20.1\%) compared with Romania Start-up Plus (27.3\%). The results suggest the possibility that negative selectivity exists within Diaspora Start-up as opposed 
to Romania Start-up Plus, so further research is needed to explore the factors behind the outcomes. This finding challenges the idea that this policy of stimulating return migrants' entrepreneurship is more beneficial than encouraging entrepreneurship among individuals already living in Romania.

In order to prevent a negative self-selectedness effect within future Diaspora Start-up programs more attention should by paid to the eligibility criteria and specific support mechanisms should be added for the integration of migrants upon return. Given these results, future research on the Diaspora Start-up program can pay attention to the multiple selection processes that affect which migrants ultimately become entrepreneurs in their home country through governmental programs. First, self-selection effects should be explored because different types of support mechanisms-in this case, a maximum subsidy of 40,000 euros-are appealing to certain individuals. For example, financial support attracts migrants who are less integrated in their destination country and migrants who can mobilize other resources in their entrepreneurial projects. In addition, the migration scholarship reviewed in this paper emphasizes that such programs can be made appealing for larger categories of migrants by supporting their business plans (e.g., non-refundable grants or access to credit mechanism) along with their individual or familial reintegration upon return (e.g., taking into consideration that decisions to return and to invest is influenced by migrants' partners reintegration into labour market and/or their children reintegration into the educational system). This means that elaborating a multidimensional policy framework for return migrants will be more efficient that support schemes focused exclusively on their business intentions.

Moving towards the regional level, our results suggest that some counties require stronger assistance from the Romanian Ministry of European Funds and its agencies because the programs had very low level of performance in particular regional contexts. For instance, there are six counties in which the number of creative startups within the Diaspora Start-up program was zero and several others with very low values. Based on these analyses we can argue that public policies designed for supporting the emergence of start-ups should include additional factors for addressing regional discrepancies. A higher level of flexibility is therefore essential for this type of policies and administrative sciences can directly contribute for evaluating and adjusting the programs. In addition, regional projects should be designed to complement the general national scheme of business creation, while exchanges of good practices can be systematized and stimulated by the ministry.

While the article introduces a series of new insights about policies designed to stimulate return migration through support mechanisms for entrepreneurship, it also has a series of limits. These are mainly linked to the scarcity of public data and microdata about the implementation of these programs. More precise analyses of these programs can be facilitated by making the selection process more transparent. These programs have had a consistent budget and required multiple levels of monitoring and supervision, but most of the information is unavailable to the public. An exten- 
sive website must be provided, as well as access to anonymized data at an individual level rather than information aggregated around criteria that have low explanatory power. Greater transparency is important to encourage not only academic research but also an improved level of trust in government policies addressed to migrants. Finally, access to these data can contribute to a better adaptation of the future programs to the entrepreneurial needs of returning migrants as well as to assure a higher level of inclusiveness and equity.

\section{References:}

1. Black, R., King, R. and Tiemoko, R., 'Migration, Return and Small Enterprise Development in Ghana: A Route out of Poverty?', International Workshop on Migration and Poverty in West Africa, Sussex Centre for Migration Research, 2003, pp. 1-22.

2. Boros, L. and Hegedűs, G., 'European National Policies Aimed at Stimulating Return Migration', in Nadler, R., Kovács, Z., Glorius, B. and Lang, T. (eds.), Return Migration and Regional Development in Europe. Mobility against the Stream, London: Palgrave Macmillan, 2016, pp. 333-357.

3. Cojanu, V., Pîslaru, D.N. and Botezatu, E., Industriile creative: potențial de creștere în România şi în context European (Creative Industries: Growth Potential in Romania and in the European Context), Bucharest: Institutul European din România, 2016.

4. Cooke, P. and De Propris, L., 'A Policy Agenda for EU Smart Growth: The Role of Creative and Cultural Industries', 2011, Policy Studies, vol. 32, no. 4, pp. 365-375.

5. Cosciug, A., 'Transnational Motorways: The Secondhand Car Trade in a Country of Emigration', 2017, Anthropology News.

6. Croitoru, A., 'Alin Rus, The Mineriads: Between Political Manipulation and Workers' Solidarity, Bucharest, Curtea Veche, 2007', 2011, Journal of Comparative Research in Anthropology and Sociology, vol. 2, no. 1, pp. 229-233.

7. Croitoru, A., 'Great Expectations: A Regional Study of Entrepreneurship among Romanian Return Migrants', 2020, Sage Open, vol. 10, no. 2, pp. 1-18.

8. Croitoru, A., 'Stimulating Return Migration to Romania: A Multi-method Study of Returnees' Endorsement of Entrepreneurship Policies', 2021, fournal of Contemporary European Studies, vol. 29, no. 2, pp. 264-281.

9. Croitoru, A., Antreprenoriatul în migrația românească (Entrepreneurship in Romanian Migration), Bucharest: Tritonic, 2016.

10. Croitoru, C., Cojanu, V., Mucică, D. and Becuț, A., Cartea albă pentru activarea potențialului economic al sectoarelor culturale și creative din România (The White Paper for Activating the Economic Potential of the Cultural and Creative Sectors in Romania), Bucharest: Pro Universitaria, 2016.

11. Dustmann, C. and Kirchkamp, O., 'The Optimal Migration Duration and Activity Choice after Remigration', 2002, Journal of Development Economics, vol. 67, pp. 351-372.

12. European Commission, 'Proposal for a Regulation of the European Parliament and of the Council on Establishing the Creative Europe Programme', $\operatorname{COM}(2011) 785$ final, 2011, [Online] available at http://www.europarl.europa.eu/meetdocs/2009_2014/documents/ com/com_com(2011)0785_/com_com(2011)0785_en.pdf, accessed on April 2, 2020. 
13. European Commission, Communication from The Commission to The European Parliament, The Council, The European Economic and Social Committee and The Committee of The Regions, 'Entrepreneurship 2020 Action Plan - Reigniting the Entrepreneurial Spirit in Europe', Brussels, 2013, [Online] available at https://eur-lex.europa.eu/LexUriServ/Lex UriServ.do?uri=COM:2012:0795:FIN:EN:PDF, accessed on December 20, 2020.

14. Fries-Tersch, E., Jones, M., Böök, B., De Keyser, L. and Tugran, T., 2019 Annual Report on Intra-EU Labour Mobility, Luxembourg, 2020, [Online] available at https://ec.europa.eu/ social $/$ main.jsp?catId=738\&furtherPubs=yes\&langId=en $\&$ pubId $=8242$, accessed on May $15,2020$.

15. Higgs, P., Cunningham, S. and Bakhshi, H., Beyond the Creative Industries: Mapping the Creative Economy in the United Kingdom, United Kingdom: Nesta, 2008.

16. Karolak, M., 'Returning for (Dis)Integration in the Labour Market? The Careers of Labour Migrants Returning to Poland from the United Kingdom', in Hinger, S. and Schweitzer, R. (eds.), Politics of (Dis)Integration, Cham: Springer, 2020, pp. 101-120.

17. Kelley, D., Singer, S. and Herrington, M., Global Entrepreneurship Monitor. Global Report 2015/16, Wellesley, Global Entrepreneurship Research Association (GERA), 2016.

18. Kḷave, E. and Šūpule, I., 'Return Migration Process in Policy and Practice', in Kaša, R. and Mierina, I. (eds.), The Emigrant Communities of Latvia. National Identity, Transnational Belonging, and Diaspora Politics, Cham: Springer, 2019, pp. 261-286.

19. Lesińska, M., 'The Dilemmas of Policy Towards Return Migration. The Case of Poland after the EU Accession', 2013, Central and Eastern European Migration Review, vol. 2, no. 1, pp. 77-90.

20. Liu, X., Lu, J., Filatotchev, I., Trevor, B. and Wright, M., 'Returnee Entrepreneurs, Knowledge Spillovers and Innovation in High-Tech Firms in Emerging Economies', 2010, Journal of International Business Studies, vol. 41, pp. 1183-1197.

21. Lulle, A., Zaiga, K. and Bauls, A., 'Diverse Return Mobilities and Evolving Identities among Returnees in Latvia', in Anghel, R.G., Fauser, M. and Boccagni, P. (eds.), Transnational Return and Social Change. Hierarchies, Identities and Ideas, London: Anthem Press, 2019.

22. Mccormick, B. and Wahba, J., 'Overseas Work Experience, Savings and Entrepreneurship Amongst Return Migrants to LDCs', 2001, Scottish fournal of Political Economy, vol. 48, no. 2, pp. 164-178.

23. Mihalache, F. and Croitoru, A., Mediul rural românesc: evoluţii şi involuţii. Schimbare socială şi antreprenoriat (Romanian Rural Environment: Evolutions and Involutions. Social Change and Entrepreneurship), Bucharest: Editura Expert, 2011.

24. Mihalache, F., Mediul rural între 1990 și 2020. Transformări și decalaje [Rural Environment Between 1990 and 2020. Transformations and Shifts], Cluj-Napoca: Presa Universitară Clujeană, 2020.

25. Ministry of Economic Development, Entrepreneurship in Poland, Warsaw, 2017, [Online] available at https://www.gov.pl/attachment/a4264f06-619a-4bd1-875c-97ef25ec1ded, accessed on May 14, 2020.

26. Potot, S., 'Transitioning Strategies of Economic Survival: Romanian Migration During the Transition Process', in Black, R., Engbersen, G., Okólski, M. and Panţîru, C. (eds.), A Continent Moving West?: EU Enlargement and Labour Migration from Central and Eastern Europe, Amsterdam: Amsterdam University Press, 2010, pp. 249-270. 
27. Sabar, G. and Pagis, M., 'Enhancing the Spirit of Entrepreneurship: African Labor Migrants Returning from Israel', 2015, Migration Studies, vol. 3, no. 2, pp. 260-280.

28. Sandu, D., 'Destination Selection among Romanian Migrants in Times of Crisis: An Origin Integrated Approach', 2017, Romanian fournal of Population Studies, vol. 11, no. 2, pp. 145-192.

29. Sandu, D., Lumile sociale ale migrației românești în străinătate (The Social Worlds of Romanian Migration Abroad), Iași: Polirom, 2010.

30. Sandu, D., Toth, G. and Tudor, E., 'The Nexus of Motivation-Experience in the Migration Process of Young Romanians', 2018, Population, Space and Place, vol. 24, no. 1, pp. 1-16.

31. Schmutzler, J., Andonova, V. and Perez-Lopez, J., 'The Role of Diaspora in OpportunityDriven Entrepreneurial Ecosystems: A Mixed-Methods Study of Balkan Economies', 2021, International Entrepreneurship and Management Journal, vol. 17, pp. 693-729.

32. Schumpeter, J.A., The Theory of Economic Development. An Inquiry into Profits, Capital, Credit, Interest, and the Business Cycle, New Brunswick: Transaction Publishers, 2008.

33. Șerban, M. and Croitoru, A., 'Do Return Migration Policies Matter? A Typology of Young Romanian Returnees' Attitudes towards Return Policies', 2018, Social Change Review, vol. 16, no. 1-2, pp. 9-34.

34. Șerban, M., 'Migration Policies from Origin Perspective in the Case of Romania. Testing a Definition', 2015, Journal of Community Positive Practices, vol. XV, pp. 72-93.

35. Sinatti, G., 'Come Back, Invest, and Advance the Country': Policy Myths and Migrant Realities of Return and Development in Senegal', in Åkesson, L. and Eriksson Baaz, M. (eds.), Africa's Return Migrants: The New Developers?, London: Zed Books, 2015, pp. 87-108.

36. Stoica, C.A., 'Capitalism from Below: An Exploratory Analysis of Small Entrepreneurship in Hungary, Poland and Romania', 2021, Romanian fournal of Society and Politics, vol. 1, pp. 71-102.

37. Stoica, C.A., 'From Good Communists to Even Better Capitalists? Entrepreneurial Pathways in Post-Socialist Romania', 2004, East European Politics and Societies, vol. 18, no. 2, pp. 236-277.

38. Sucală, V.I., Inside the East European Planned Economy. State Planning, Factory and Manager, London: Routledge, 2018.

39. Swain, N., Green Barons, Force-of-Circumstance Entrepreneurs, Impotent Mayors. Rural Change in the Early Years of Post-Socialist Capitalist Democracy, Budapest \& New York: Central European University Press, 2013.

40. Varga, M., Worker Protests in Post-Communist Romania and Ukraine. Striking with Tied Hands, Manchester and New York: Manchester University Press, 2014.

41. Vlase, I. and Croitoru, A., 'Nesting Self-employment in Education, Work and Family Trajectories of Romanian Migrant Returnees', 2019, Current Sociology, vol. 67, no. 5, pp. 778-797.

42. Voicu, Ș. and Dragomir, A., Vitalitatea culturală a orașelor din România (The Cultural Vitality of Romanian Cities), Bucharest: Institutul Național pentru Cercetare și Formare Culturală, 2016.

43. Volintiru, C. and Miron, D., 'Business Environment and Creative Industries in Romania', 2014, Amfiteatru Economic, vol. 17, no. 38, pp. 288-298. 
44. Von Bloh, J., Mandakovic, V., Apablaza, M., Amorós, J.E. and Sternberg, R., 'Transnational Entrepreneurs: Opportunity or Necessity Driven? Empirical Evidence from Two Dynamic Economies from Latin America and Europe', 2020, fournal of Ethnic and Migration Studies, vol. 46, no. 10, pp. 2008-2026.

45. Wahba, J., 'Selection, Selection, Selection: The Impact of Return Migration', 2015, fournal of Population Economics, vol. 28, pp. 535-563.

46. White, A., 'Polish Returnees' Livelihood Strategies, Social Remittances and Influence on Communities of Origin', in Anghel, R.G., Fauser, M. and Boccagni, P. (eds.), Transnational Return and Social Change. Hierarchies, Identities and Ideas, London: Anthem Press, 2019.

47. White, A., 'Polish Return and Double Return Migration', 2014, Europe-Asia Studies, vol. 66, no. 1 , pp. 25-49.

48. Williams, A.M., 'International Labour Migration and Tacit Knowledge Transactions: A Multi-Level Perspective', 2007, Global Networks, vol. 7, no. 1, pp. 29-50.

49. Wolchik, S.L. and Curry, J.L., Central and East European Politics: From Communism to Democracy, Lanham: Rowman \& Littlefield, 2018.

50. Zareva, I., 'Policies for Encouraging the Return of Bulgarian Migrants to Bulgaria', 2018, Economic Studies fournal, vol. 2, pp. 65-79. 
Annex 1: Number of start-ups created within the two programs (at county level)

\begin{tabular}{|c|c|c|c|c|}
\hline & \multicolumn{2}{|c|}{ Romania Start-up Plus } & \multicolumn{2}{|c|}{ Diaspora Start-up } \\
\hline & $\begin{array}{l}\text { Total number } \\
\text { of start-ups }\end{array}$ & $\begin{array}{l}\text { Number of start-ups } \\
\text { in the creative industries* }\end{array}$ & $\begin{array}{l}\text { Total number } \\
\text { of start-ups }\end{array}$ & $\begin{array}{l}\text { Number of start-ups } \\
\text { in the creative industries* }\end{array}$ \\
\hline Alba & 339 & 78 & 56 & 11 \\
\hline Arad & 185 & 46 & 12 & 2 \\
\hline Arges & 228 & 75 & 18 & 4 \\
\hline Bacau & 125 & 38 & 36 & 3 \\
\hline Bihor & 136 & 40 & 26 & 5 \\
\hline Bistrita-Nasaud & 66 & 20 & 18 & 4 \\
\hline Botosani & 79 & 22 & 9 & 0 \\
\hline Braila & 132 & 36 & 10 & 1 \\
\hline Brasov & 311 & 83 & 101 & 22 \\
\hline Buzau & 140 & 37 & 11 & 1 \\
\hline Calarasi & 88 & 28 & 5 & 0 \\
\hline Caras-Severin & 128 & 22 & 17 & 2 \\
\hline Cluj & 413 & 154 & 66 & 16 \\
\hline Constanta & 379 & 96 & 24 & 8 \\
\hline Covasna & 158 & 61 & 29 & 6 \\
\hline Dambovita & 223 & 76 & 15 & 4 \\
\hline Dolj & 466 & 127 & 23 & 4 \\
\hline Galati & 195 & 47 & 22 & 2 \\
\hline Giurgiu & 86 & 29 & 8 & 4 \\
\hline Gorj & 215 & 49 & 26 & 6 \\
\hline Harghita & 175 & 53 & 24 & 14 \\
\hline Hunedoara & 120 & 18 & 18 & 1 \\
\hline Ialomita & 84 & 36 & 6 & 0 \\
\hline Iasi & 360 & 88 & 100 & 28 \\
\hline Maramures & 154 & 41 & 17 & 2 \\
\hline Mehedinti & 121 & 26 & 9 & 0 \\
\hline Mures & 226 & 57 & 92 & 23 \\
\hline Neamt & 138 & 37 & 16 & 3 \\
\hline Olt & 173 & 39 & 12 & 1 \\
\hline Prahova & 342 & 79 & 36 & 8 \\
\hline Salaj & 61 & 15 & 7 & 2 \\
\hline Satu Mare & 67 & 17 & 8 & 2 \\
\hline Sibiu & 257 & 61 & 33 & 10 \\
\hline Suceava & 166 & 43 & 46 & 4 \\
\hline Teleorman & 119 & 37 & 14 & 0 \\
\hline Timis & 380 & 106 & 28 & 5 \\
\hline Tulcea & 125 & 27 & 6 & 1 \\
\hline Valcea & 204 & 64 & 22 & 0 \\
\hline Vaslui & 63 & 14 & 16 & 1 \\
\hline Vrancea & 123 & 36 & 23 & 4 \\
\hline
\end{tabular}

Note: See the methodology of this article for the exact definition of the creative industries. 